\title{
ASMS News
}

\section{ASMS FALL WORKSHOP: "LIMITS TO CONFIRMATION, QUANTITATION, AND DETECTION," NOVEMBER 1-2, 1996, RADISSON HOTEL, ALEXANDRIA, VIRGINIA}

The ASMS Fall Workshop organizer is Bob Bethem of ALTA Analytical Laboratory. Trace analysis can employ various ionization and data processing techniques for acceptable detection, confirmation and quantitation. Consequently, a widely differing comprehension has evolved in the scientific literature of how to calculate the detection limit and what constitutes unambiguous confirmation. At the same time, it is clear that regulatory agencies, courts and the public expect analytical results to be defensible and precise. The workshop will strive to develop a consensus set of criteria and/or guidelines that can be used to develop and validate methods. These guidelines will address issues of specificity, accuracy, reproducibility, limit of detection and applicability. The guidelines will be formulated from statistical theory, regulatory examples and practical experiences using a wide variety of MS and MS/MS techniques. For further information, please contact ASMS, 1201 Don Diego Avenue, Santa Fe, NM 87505. Telephone (505) 989-4517.

\section{THE 9TH SANIBEL CONFERENCE: "QUADRUPOLE ION TRAPS," \\ JANUARY 25-28, 1997, SUNDIAL RESORT, SANIBEL ISLAND, FLORIDA}

The conference program will focus on fundamental and applied developments in quadrupole ion trap mass spectrometry. Topics will include fundamental principles of operation, structural characterization using MS/MS, MS ${ }^{\mathrm{n}}$ and ion-molecule reactions, use of ionization techniques such as electrospray and MALDI, and applications to biochemical and other types of systems. The format of the program will consist of invited speakers and contributed posters, with ample time for discussion. The conference organizers are Gary Glish, University of North Carolina and Raymond March, Trent University. For further information, please contact ASMS, 1201 Don Diego Avenue, Santa Fe, NM 87505. Telephone (505) 989-4517.

PII S1044-0305(96)00129-1

\section{TH ASMS CONFERENCE ON MASS SPECTROMETRY AND ALLIED TOPICS \\ JUNE 1-5, 1997, PALM SPRINGS, CALIFORNIA}

The 45th ASMS Conference will take place in Palm Springs, California, June 1-5, 1997. Conference sessions will be held in the Palm Springs Convention Center and in the nearby Wyndham Hotel. Most of the hotels providing accommodations for the conference are within walking distance of the convention center. Learn more about Palm Springs and the surrounding area on the web page at (http://www.desertresorts.com $>$.

If you would like to make suggestions for the conference program (plenary speakers, oral session topics, and/or conference workshops), please contact Robert J. Cotter, Vice President for Programs, 〈rcotter@ welchlink.welch.jhu.edu>.

The conference announcement and call for papers will be sent in October, 1996. The deadline for abstract submission will be mid-January, 1997. Watch the ASMS web page for details as they become available 〈http://www.asms.org 〉. For further information, please contact ASMS, 1201 Don Diego Avenue, Santa Fe, NM 87505. Telephone (505) 989-4517.

\section{ASMS WEB PAGE http:// www.asms.org}

Check the ASMS web page for updates and information on the following:

Fall Workshop

9th Sanibel Conference

45th ASMS Conference on Mass Spectrometry

Employment Postings

44th ASMS Conference Abstract Database. (The abstract database has been updated to reference page numbers in the "Proceedings of the 44th Conference on Mass Spectrometry and Allied Topics.")

\section{RELATED EVENTS}

ASMS is happy to announce meetings of non-profit organizations. Please supply date, name of event, and location, along with the full address, telephone number and fax of contact person. You may also include a brief description, not to exceed one paragraph of 300 characters. 